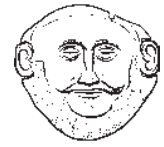

\title{
REVEALING ANTIQUITY
}

-18•

G. W. Bowersock, General Editor 



\section{NEW HEROES IN ANTIQUITY}

From Achilles to Antinoos

$$
+
$$

\section{CHRISTOPHER JONES}

Harvard University Press

Cambridge, Massachusetts

London, England

2010 
Copyright (C) 2010 by the President and Fellows of Harvard College All rights reserved

Printed in the United States of America

Library of Congress Cataloging-in-Publication Data

Jones, Christopher P., 1940-

New heroes in antiquity : from Achilles to Antinoos / Christopher Jones.

p. cm. - (Revealing antiquity ; 18)

Includes bibliographical references and index.

ISBN 978-0-674-03586-7

1. Mythology, Greek. 2. Gods, Greek. 3. Superheroes-Greece.

4. Heroes-Greece. 5. Greece-Religion. I. Title.

BL785.J66 2010

$292.2^{\prime} 11-\mathrm{dc} 22 \quad 2009011505$ 